\title{
GAMBARAN PROSES PEMBUATAN TRANSFEMORAL PROSTHESIS MENGGUNAKAN POLYCENTRIC KNEE JOINT UNTUK PASIEN AMPUTASI ATAS LUTUT
}

\author{
Ismi Dwi Syafitri, Nur Rachmat \\ Kementerian Kesehatan Politeknik Kesehatan Surakarta Jurusan Ortotik Prostetik
}

\begin{abstract}
Transfemoral Amputasi, Transfemoral Prosthesis, Polycentric Knee Joint. World Health Organization (WHO) estimated that there are 40 million amputees throughout the developing countries. Amputation in the lower limbs reached $85 \%-90 \%$ of all amputations. Transfemoral amputation because of this amputation occurs in the thigh that passed through the femur bone. Amputation causes significant gait abnormalities. amputation levels increased, the functional level is reduced, and the characteristic of the gait abnormality is immediately apparent. Transfemoral Prosthesis is artificial limb that made for above knee amputation. making process of transfemoral prosthesis includes assessment, measurement, casting, fabrication, fitting, finishing. Of all components for transfemoral patients, prosthetic knee joints are the most important components that can affect to gait stability. The choice for the type of popular passive knee mechanism is polycentric knee. The polycentric knee joint mechanism, linkage of 4 and 6 bar mechanisms have been used to increase stability during the stance and kinematic phase of the swing phase.
\end{abstract}

Keyword : Transfemoral Amputasi, Transfemoral Prosthesis, Polycentric Knee Joint.

Abstrak : Transfemoral Amputasi, Transfemoral Prosthesis, Polycentric Knee Joint. World Health Organization (WHO) memperkirakan terdapat 40 juta pasien amputasi diseluruh negara berkembang. Amputasi pada anggota gerak bawah mencapai 85\%-90\% dari seluruh amputasi. Amputasi transfemoral karena amputasi ini terjadi dipaha yang melalui tulang femur. Amputasi menyebabkan kelainan pola jalan yang signifikan. Dengan meningkatnya level amputasi maka, tingkat fungsional berkurang, dan karakteristik kelainan pola jalan semakin terlihat jelas. Transfemoral Prosthesis merupakan kaki tiruan yang digunakan untuk amputasi atas lutut. proses pembuatan transfemoral prosthesis meliputi assessment, measurement, casting, fabrication, fitting, finishing. Dari semua komponen untuk pasien transfemoral, prosthetic knee joint merupakan komponen yang paling penting yang dapat berefek pada stabilitas pola jalan. Pilihan untuk tipe mekanisme knee pasif yang popular adalah polycentric knee. Mekanisme polycentric knee joint, menggabungkan mekanisme 4 dan 6 bar telah dimanfaatkan untuk menambah stabilitas saat stance phase dan kinematik swing phase.

Kata Kunci : Transfemoral Amputasi, Transfemoral Prosthesis, Polycentric Knee Joint.

PENDAHULUAN

World Health Organization (WHO) memperkirakan terdapat 40 juta pasien amputasi diseluruh negara berkembang. Angka kejadian amputasi yang pasti di indonesia tidak diketahui 
menurut vitriana (2002) di amerika serikat terjadi 43.000 kasus per tahun dari jumlah penduduk 280.562.489 jiwa atau sekitar $0,02 \%$, sedangkan dalam raichle et al.(2008) disebutkan bahwa terjadi kasus amputasi sekitar 158.000 per tahun dari jumlah penduduk 307.212.123 atau sekitar 0,05\% (jumeno, 2009)

Terjadi peningkatan kasus amputasi di amerika serikat, baik secara jumlah maupun secara presentase dari jumlah penduduk. Amputasi pada anggota gerak bawah mencapai 85\%-90\% dari seluruh amputasi (jumeno,2009). Amputasi lebih banyak disebabkan oleh kecelakaan lalu lintas (trauma). Menurut badan pusat statistik indonesia, kecelakaan di indonesia pada tahun 2012 mencapai 117.949 kasus. Hal ini menyebabkan trauma akibat kecelakaan menjadi hal yang umum yang dapat menyebabkan cacat fisik di masyarakat.

Amputasi sebagian anggota gerak akan menyebabkan ketidakmampuan seseorang untuk melakukan aktivitas dalam derajat yang bervariasi, tergantung bagian anggota gerak yang teramputasi, usia, dan penanganan operasi. (Berke, 2008). Amputasi dapat disebabkan oleh berbagai hal diantaranya penyakit, trauma, infeksi, tumor, congenital. Amputasi pada level transfemoral sangat menantang untuk pasien melakukan operasi, prosthetist, physiotherapist, dan setiap anggota tim kesehatan. Di united states, level amputasi ini paling dikenal sebagai amputasi atas lutut (a.k.a), mengingat ditempat lain amputasi ini dikenal amputasi transfemoral karena amputasi ini terjadi dipaha yang melalui tulang femur (ülger, 2009).

\section{Transfemoral}

Prosthesis merupakan kaki tiruan yang digunakan untuk amputasi ata lutut. Individu dengan atas lutut sulit akan mengembalikan gerakan normal. Secara umum, individu dengan amputasi atas lutut harus menggunakan $80 \%$ lebih banyak energy untuk berjalan daripada seseorang yang masih memiliki tungkai normal. Hal ini disebabkan kompleksitas gerakan yang terjadi pada lutut. Untuk proses pembuatan transfemoral prosthesis meliputi: (1)assessment, (2) measurement, (3)casting, (4)fabrikasi, (5)fitting, (6)finishing. tahapan fabrikasi terdiri dari rektifikasi negative cast, filling, rektifikasi positif cast, laminasi (Berke,2008).

Amputasi menyebabkan kelainan pola jalan yang signifikan. Dengan meningkatnya level amputasi maka, tingkat fungsional berkurang, dan karakteristik kelainan pola jalan semakin terlihat jelas. Seperti halnya pola jalan pada pasien transfemoral berbeda dari pola jalan yang normal. Sebagian besar pasien mengalami kesulitan saat berdiri (Nolan, 2000)

Perubahan pada pola jalan, ketidakstabilan dalam tahapan berdiri, dan fokus mental saat menggunakan prosthesis meningkatkan konsumsi energy yang menghasilkan prosthetic knee yang tidak stabil. Pasien disebabkan karena faktor fisik dan psikologi (pauley,2006).

Setiap bagian ekstremitas bawah berkontribusi terhadap kestabilan pola jalan, khususnya joint. Ankle dan knee joint bertanggung jawab untuk load bearing, artikulasi, dan dan semua pola jalan dinamik. Oleh karena itu, kehilangan knee dan ankle joint karena amputasi transfemoral sangat berefek besar pada pola jalan (ramakrishnan, 2015).

Perkembangan teknologi pada penggunaan prosthetic membuka lebih luas terhadap pilihan knee, oleh karena itu, memberikan kinematika berjalan pada 
pasien amputasi transfemoral lebih baik. Namun, prosthetic modern lebih mahal, karena kompleks dan biaya knee, yang mana sebagian besar komponen penting pada transfemoral prosthesis. Pemilihan knee adalah proses kompleks yang melibatkan rehabilitasi individu yang kompleks dengan penilaian sebelumnya terhadap semua elemen struktur tubuh dan kinerja fisik dan menetapkan tujuan fungsional dengan tujuan prosthesis menjadi unit biomechanical baru. karakteristik utama pada pasien yang menetapkan pilihan pada lower limb prosthesis, dalam kasus knee ini adalah gaya hidup, usia, berat, gaya fisik dan panjang stump pasien (Gabbiadini,2011).

Salah satu cara efektif untuk mengembalikan kembali kemampuan berjalan yaitu dengan menggunakan design prosthetic yang tepat. terdapat banyak pilihan yang tersedia untuk komponen prosthesis, bagaimanapun kriteria prescription berdasarkan pengalaman subjektif pada terapis dan prosthetis. Dari semua komponen untuk pasien transfemoral, prosthetic knee joint merupakan komponen yang paling penting yang dapat berefek pada stabilitas pola jalan (mohanty, 2017).

Prosthetic knee harus mengganti fungsi dari knee-nya untuk menyediakan stabilitas knee selama weight bearing saat stance pahase dan mengontrol pergerakan selama swing phase. Ketidakstabilan pada prosthetic knee sering menyebabkan gait deviasi, peningkatan konsumsi energi untuk ambulasi dan mungkin dapat menghasilkan prosthesis knee fleksi selama stance. Ketidaktepatan mekanisme swing phase yang sesuai dapat menyebabkan gait deviasi dan meningkatkan konsumsi energy pada ambulasi. Prosthetis dan fisioterapi harus mempertimbangkan kemampuan setiap pasien dan tujuan fungsional untuk menentukkan prosthetis knee yang paling sesuai, dan yang mana kemungkinan akan menghasilkan pola jalan yang lebih baik (Silver, 2009).

Selama stance phase, knee harus menyediakan stabilitas selama weight bearing sementara juga memfasilitasi transisi dari stance ke swing phase. Anatomical knee yang normal dapat memenuhi kecenderungan efisiensi yang berbeda melalui interaksi struktur anatomical, aktivitas otot, dan ground reaction force vector $(G R F V)$. Standar mekanisme prosthetic knee tidak menggantikan komponen muscular pada anatomical knee, dan tidak dapat menyesuaikan kecenderungan ini. Sebagai hasilnya mungkin menyediakan untuk pasien TF antara stabilitas stance phase dan permintaan untuk memulai swing phase, dan permintaan ini dapat menyebabkan gait deviasi dan meningkatakan kecenderungan pada musculature pada hip stump (Silver, 2009).

Stabilitas stance phase pada desain prosthetic knee memiliki 2 faktor yang berkontribusi : stabilitas mekanikal yang melekat pada mekanisme itu sendiri, dan stabilitas yang sengaja disediakan oleh otot hip yang tersisa pada pasien TF. Mekanikal stabilitas pada prosthetic knee yang tersedia dengan alignment center of rotation pada posterior knee prosthetic ke GRFV selama stance. Hasil ini pada moment pasif ekstension pada knee, mencegah knee fleksi saat weight bearing dan selama mungkin $G R F V$ tetap anterior pada rotasi knee axis (Silver, 2009).

Menyediakan stabilitas selama stance tidak hanya fungsi dari prosthetic knee. Kehalusan transisi dari stance ke 
swing phase dan mengontrol pergerakan knee selama swing phase dapat disediakan melalui penggunaan mekanisme kontrol swing phase seperti alat constant friction dan hydraulic. Menonaktifkan control stance phase biasanya terjadi karena pergerakan GRFV anterior ke knee joint pada mid- ke yang terbaru. Untuk mengatasi stabilitas alignment pada prosthetic knee bagaimanapun, permintaan bahwa pasien mengaktifkan penggunaan fleksi moment pada hip. Ini menggerakan posterior $G R F V$ ke center of rotation pada prosthetic knee dan membolehkan pasien untuk memfleksikan knee dan memulai swing. Design knee prosthetic menyediakan peningkatan stabilitas alignment selama stance phase yang mungkin menyebabkan peningkatan pada hip fleksi moment untuk memulai knee fleksi selama swing phase, menghasilkan ketersediaan antara upaya stabilitas stance phase dan memulai swing phase (Silver, 2009).

Knee joint yang terdistribusi di negara berkembang adalah dengan tipe pasif, murah, dan dengan desain yang simple (Arelekatti,2016) . terdapat 5 jenis pasif knee locking, yaitu manual, polycentric, single axis, weight activated, and knee with exterior hinges. Single-axisself-locking knee menggunakan constant friction selama fase swing phase, sedangkan mekanisme self-locking diaktifkan dengan mentransfer beban pada prosthesis, yangmana mencegah knee mengunci selama tahapan berdiri, dan hanya membolehkan untuk flexionextension pattern (open-closed knee) (Silver, 2009). Single axis dengan dan tanpa manual lock telah ditemukan dan sebagian besar didistribusikan dinegara berkembang. Single axis joint dengan manual lock membuat pengguna melakukan gait deviasi circumduction untuk mencapai toe clearance saat swing phase dan menaikkan hip selama stance phase. Single axis joint tanpa manual lock menyebabkan pola jalan yang hyperstable, dimana saat stace phase sampai transisi swing phase (melewati knee fleksi) terlambat. Jika tidak di alignment dengan benar, mereka dapat menyebabkan knee "fleksi" selama stance awal menyebabkan pengguna tersandung atau jatuh (Arelekatti,2016).

Pilihan untuk tipe mekanisme knee pasif yang popular adalah polycentric knee (ramakrishnan, 2015). polycentric knee adalah jenis knee yang paling stabil dari semua jenis knee kecuali manual lock knee. Polycentric knee joint berisi variabel centre of rotation dan menyediakan keamanan pada semua fase berjalan. jenis knee ini memiliki hubungan yang kompleks yang mempertahankan instantaneous center of rotation (ICR), maksudnya bahwa center of rotation knee selalu bergerak selama stance phase. pergerakan ICR membantu mempertahankan knee center dibelakang ground reaction force yangmana menyediakan stabilitas. sebagian besar polycentric knee, center of rotation ini ditempatkan proksimal dan posterior, terhadap otot perut hamstring, untuk maksimum stabilitas. Mempertahankan untuk fleksi adan ekstensi dikontrol melalui friction yang berada di polycentric knee joint, yangmana di atur oleh prosthetist untuk level aktivitas pasien. karena stabilitas yang melekat pada unit knee ini, polycentric knee sering diindikasikan untuk pasien amputasi bilateral dan pasien yang tidak dapat ambulasi dengan aman dengan tipe knee lainnya. tipe knee ini juga diresepkan untuk pasien yang memiliki long stump 
dan pasien knee disarticulation karena efek yang pendek pada polycentric knee saat tahap awal swing phase (Berke, 2008).

Polycentric joint dikembangkan oleh d-rev telah di gunakan juga di negara-negara berkembang (arelekatti 2016). polycentric knee joint, posisi instantaneous center of rotation (ICR) secara terus menerus berubah dengan mengubah sudut knee fleksi. Mekanisme polycentric knee joint, menggabungkan mekanisme 4 dan 6 bar telah dimanfaatkan untuk menambah stabilitas saat stance phase dan kinematik swing phase. Polycentric knee joint terbuat dari baja atau duralumunium lebih disukai, dimana menggunakan titanium atau carbon, dapat membuat lebih ringan, tetapi lebih mahal (mohanty, 2017).

Dengan latar belakang inilah, maka peneliti ingin mengetahui tentang stabilitas saat menggunakan menggunakan prosthetic polycentric knee joint.

\section{METODE PENELITIAN}

Penelitian ini menggunakan penelitian kualitatif. Penelitian kualitatif menghasilkan mengolah data yang bersifat deskriptif. Dalam penelitian ini, penulis ingin memberikan deskripsi mengenai stabilitas saat menggunakan polycentric knee joint, dan tidak ada hipotesis yang diuji, meskipun menggunakan teori yang ada. Pendekatan penelitian menggunakan murni kualitatif dengan menggunakan metode kontak langsung, yaitu wawancara. Peneliti akan melakukan penelitian kualitatif dengan metode pengumpulan data secara wawancara terfokus (poerwandari. 2009).

Stabilitas pada pola jalan pasien transfemoral menggunakan polycentric knee joint akan diteliti dari data yang konkrit. Subjek yang akan diteliti adalah pasien transfemoral amputasi yang menggunakan single axis knee joint dengan cara wawancara terfokus pada pasien tersebut dan observasi saat menggunakan dua jenis knee joint.

Dalam penelitian ini, peneliti menggunakan metode penelitian kualitatif dengan teknik penelitian studi kasus (case study). Studi kasus adalah suatu bentuk penelitian (inquiry) atau studi tentang suatu masalah yang memiliki sifat kekhususan (particularity), dapat dilakukan baik dengan pendekatan kualitatif maupun kuantitatif, dengan sasaran perorangan (individual) maupun kelompok, bahkan masyarakat luas (basuki (2006). Stake (dalam basuki, 2006) menambahkan bahwa penekanan studi kasus adalah memaksimalkan pemahaman tentang kasus yang dipelajari dan bukan untuk mendapatkan generalisasi, kasusnya dapat bersifat kompleks maupun sederhana dan waktu untuk mempelajari dapat pendek atau panjang, tergantung waktu untuk berkonsentrasi.

Pada studi kasus intrinsik, peneliti mempunyai ketertarikan atau kepedulian pada kasus ini (wilig, 2001 ), yaitu stabilitas saat menggunakan single axis knee joint dan saat menggunakan polycentric knee joint pada pasien transfemoral prosthesis tanpa menghasilkan konsep-konsep atau teori, ataupun tanpa upaya menggeneralisasi.

Dalam penelitian ini peneliti memutuskan untuk menggunakan metode observasi langsung dimana peneliti pengamatan yang dilakukan secara langsung saat melakukan proses fitting saat subjek melakukan tahapan dynamic alignment yaitu berjalan menggunakan 
transfemoral prosthesis dengan single axis knee joint dan polycentric knee joint sehingga pola jalan dapat diamati secara langsung. Pada penelitian ini, peneliti melakukan observasi pada saat pasien melakukan proses fitting. Observasi dilakukan dengan cara mengamati pola jalan saat proses fitting dengan menggunakan transfemoral prosthesis dengan polycentric knee joint.

Peneliti akan melakukan wawancara dengan pedoman wawancara yang terbuka. Pedoman wawancara ditulis secara umum, dengan pertanyaan dan penjabarannya yang bersifat fleksibel dalam kalimat. Peneliti akan melakukan wawancara kepada pasien pada saat proses assessment dan fitting, yang diharapkan dapat mengetahui secara rinci tentang kondisinya saat menggunakan polycentric knee joint transfemoral prosthesis. Pertanyaan wawancara terdiri atas pertanyaan tentang kondisi subjek saat menggunakan pertanyaan tentang kondisi subjek saat menggunakan polycentric knee joint.

Subjek penelitian ini adalah satu orang pengguna transfemoral prosthesis dengan single axis manual lock. Alasan mengambil satu subjek karena peneliti ingin melihat stabilitas pola jalan pada saat menggunakan knee joint single axis dengan manual lock dan saat menggunakan polycentric knee joint.

\section{HASIL PENELITIAN}

Pasien masih mengalami phantom sensation dan phantom pain. Prosthesis sebelumnya terlalu tinggi $1,5 \mathrm{~cm}$ dari sisi tungkai yang normal, yang menyebabkan tidak nyaman dan berpengaruh terhadap pola jalan yaitu munculnya gait deviasi circumduction. Pasien tidak dapat menggunakan single axis knee joint dengan manual lock karena mudah fleksi yang menyebabkan tidak seimbang saat digunakan. Karena ketidaknyamanan prosthesis pasien menggunakan prosthesis hanya 1 bulan setelah prosthesis diserahkan, untuk bulan berikutnya pasien memilih menggunakan kruk dengan alasan lebih nyaman dan mobilitasnya lebih cepat saat digunakan untuk beraktifitas dibandingkan saat menggunakan prosthesis. Tetapi prosthesisnya masih digunakan hanya saat pasien ada acara penting saja.

Saat menggunakan prosthesis dengan polycentric knee joint pasien lebih stabil dan terdapat perubahan pola jalan dan lebih nyaman saat menggunakan joint jenis ini.

Transfemoral prosthesis adalah alat ganti tungkai bawah untuk pasien yang mengalami amputasi sampai tulang femur (Berke,2008). Untuk pembuatan prosthesis melalui beberapa tahapan yaitu assessment, yangmana proses wawancara masuk dalan tahapan ini dan hasil dari kita mengetahui kondisi pasien meliputi kekuatan otot (MMT) dan luas gerak sendi (ROM) didapat dari tahap ini. Untuk alat yang digunakan adalah blanko ukur, alat tulis, goniometer ( CSPO, 1999).

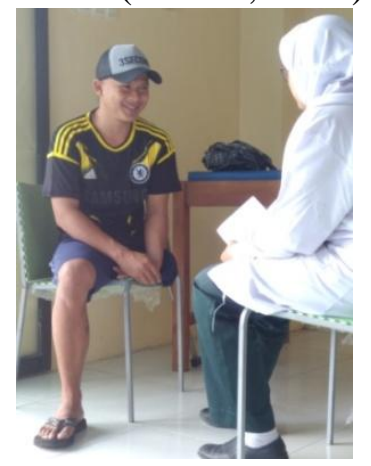

Tahapan yang kedua adalah tahapan pengukuran (measurement) stump pasien dan sisi tungkai yang normal. Sebelum dilakukan pengukuran lakukan 
penandaan pada stump. Pakaikan stockinet basah pada stump pasien dan buat lubang di ujung atas depan dan belakang stockinet untuk diikatkan dengan tali rafiah yang dibuat menyilang di bahu pasien yang berguna untuk mengencangkan stockinet supaya tidak bergeser atau lepas setelah dilakukan penandaan. Selanjutnya melakukan penandaan pada stump pasien, meliputi: (1) trochantor mayor, (2) garis interval (setiap $2 \mathrm{~cm}, 3 \mathrm{~cm}$ atau $5 \mathrm{~cm}$ ), (3) adductor tendon, (4) distal end of femur ( CSPO, 1999).

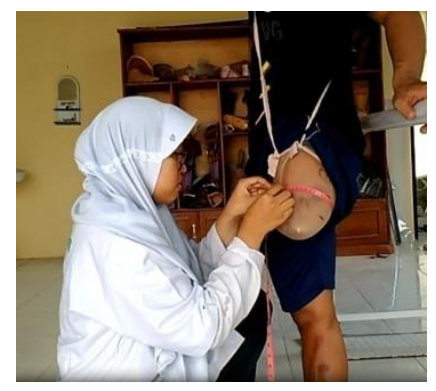

Dan selanjutnya pengukuran pada stump, yaitu: (1) Panjang stump (dari ischial tuberosity - ujung stump \& dari ischial tuberosity - ujung femur), (2) Circumference pertama (dari perineum; dengan tekanan, tanpa tekanan), (3) Jarak antar interval, (4) Circumference setiap interval, (5) Diameter A-P (dari ischial tuberosity/ tempat yang diduduki pasien adductor tendon), (6) Diameter M-L (dari adductor tendon - trochantor mayor; diukur saat pasien duduk) ( CSPO, 1999 ).

Dan lakukan pengukuran pada sisi tungkai yang normal untuk menjadi patokan saat merangkai prosthesis diukur dalam posisi berdiri yang diukur adalah : (1) Panjang sound leg dari ischial tuberosity sampai ke lantai, (2) Pasien dalam posisi duduk, (3) Panjang tungkai bawah (tibial plateu sampai lantai; pasien duduk $90^{\circ}$ ), (4) Circumference tungkai terbesar, (5) Circumference tungkai terkecil, (6) Jarak antara tungkai terbesar dengan lantai, (7) Jarak antara tungkai terkecil dengan lantai, (8) Panjang foot, (9) Tinggi heel sepatu yang digunakan pasien. Untuk alat dan bahan yang digunakan adalah : (1) Blangko pengukuran, (2) Mid line, (3) Pensil Air, (4) Alat tulis, Goniometer, (5) Midline, (6) caliper, (7) Plastic wrap, (8) stockinet, (9) tali raffia, (10) ember, (11) Air.

Tahapan ketiga adalah tahapan pengambilan cetakan stump pasien (casting) yang nantinya akan menghasilkan negative cast. Sebelum dilakukan casting memberikan pengarahan dan sedikit penjelasan kepada pasien tentang proses apa saja yang akan dilakukan, sehingga pasien dapat mengikuti proses dengan baik dan tidak menyinggung privasi pasien. Selanjutnya persiapkan bahan dan alat yang dibutuhkan, yaitu: (1) Plaster of paris bandage (P.O.P Bandage), (2) Air, (3) Stockinet, (4) Plastik wrap, (4) Pensil air, (5) Gunting / cutter, (6) Kursi casting, (7) Alas casting, (8) Ember, (9) Handuk/kain, (10) Rafia, (11) gunting/cutter. Selama proses casting pasien dalam posisi berdiri dan sebelum dibalutkan P.O.P lakukan latihan hand position untuk mengetahui gambaran letak dari ischial tuberosity dan gambaran posisi tangan yang membentuk quadrilateral socket .

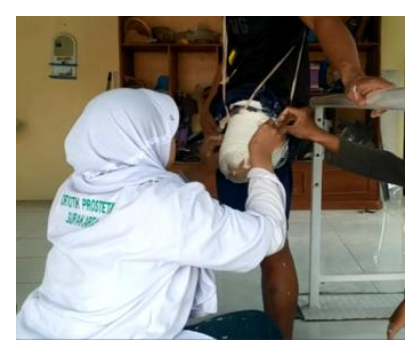


Dalam pembalutan P.O.P bandage dilakukan menggunakan teknik slab dan wrapping, untuk teknik slab lakukan pengukuran panjang P.O.P bandage dari adductor tendon sampai melingkupi bagian atas trochantor mayor dengan ketebalan 3-4 lapis. Pada bagian tengah P.O.P bandage, buat notch dengan lebar 4 $\mathrm{cm}$. Selanjutnya rendam P.O.P bandage dalam air dan peras kemudian balutkan pada stump pasien dari adductor tendon sampai bagian atas trochantor mayor (horizontal). Pastikan notch berada pada aductor tendon. Selanjutnya menggunakan teknik wrapping, yaitu rendam P.O.P Bandage dalam air, kemudian peras dan balutkan memutar mulai dari pelvis ke bagian distal stump dengan ketebalan 3 lapis, massage. Lakukan penekanan pada ischial tuberosity, medial wall dan scarpa triangle untuk membentuk quadrilateral dan penekanan pada $1 / 3$ proksimal lateral untuk memberikan lateral support. Dan alignment pada negative cast dengan menggunakan plumb line pada anterior wall dan lateral wall untuk mengetahui sudut fleksi dan abduksi stump dan tandai menggunakan pensil air. Lepaskan negative cast dari stump pasien dan lakukan pengecekkan supaya mengetahui kekurangan dari negative cast dan perbaikkan yang harus dilakukan.

Tahapan keempat fabrikasi yang merupakan proses pembuatan socket, baik hard socket maupun soft socket. Dalam tahapan ini meliputi rektifikasi negative cast, filling negative cast, rektifikasi positif cast, laminasi, assembling dan alignment.

Tahap rektifikasi cast bertujuan untuk memudahkan membentuk quadrilateral dan mengetahui apakah cast sudah memiliki bentuk dan simetri yang tepat di medio-lateral axis. Yang dilakukan dalam tahapan ini, adalah mengecek ukuran negative cast dan lakukan penandaan ulang, Potong trimeline sesuai garis yang telah dibuat saat pengecekan cast, lakukan penambahan di posterior wall untuk membentuk ischial seat. Pastikan sudut luar antara dinding medial dan posterior membentuk sudut $90^{\circ}$. Melakukan rektifikasi pada medial wall : 1/3 proksimal dibuat flat dan vertical, Proksimal medial wall dibuat turun $0,5 \mathrm{~cm}$ untuk pubis ramus dan adductor tendon. Melakukan rektifikasi pada posterior wall : Bentuk sudut $100^{\circ}$ (antara dinding medial dan posterior ), Ischial seat dibuat horizontal dan flat. Rektifikasi pada anterior wall : penambahan pada segitiga scarpa, bagian proksimal dibuat flare / melengkung ke luar. Rektifikasi pada lateral wall : Lakukan penambahan pada $1 / 3$ proksimal (di atas trochantor mayor), bagian proksimal dibuat flare / melengkung ke luar. Sesuaikan diameter A-P cast, Sesuaikan diameter M-L cast, Sesuaikan sudut fleksi, Sesuaikan sudut adduksi, yang perlu diperhatikan adalah tuberositas isia diposisikan 1,5-2,5 cm lateral dari medial wall, tendon adductor longus berada pada sudut antara medial dan anterior wall, cekungan pada anterior femoral triangle selevel dengan ischia tuberositi titik terdalamnya ada pada segitiga medial wall.

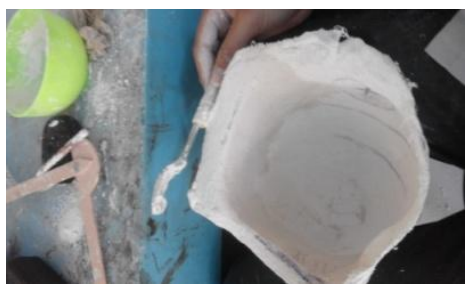

Selanjutnya tahap filling negative cast dengan campuran adonan dari gipsum 
powder dan air. Sebelum adonan di tuangkan tutup mengelilingi bagian proksimal menggunakan p.o.p bandage sampai ketinggian sama, dan masukkan tangkai besi yang sudah di beri penjepit ke dalam negative cast dan tuangkan adonan gipsum.

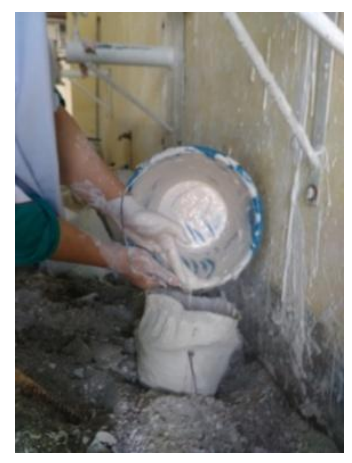

Setelah hasil filling mengeras, membuka cetakan negative cast dan menghasilkan cetakan berupa positif cast. Tandai ulang di positif cast dan mengukur ulang dan bandingkan dengan blanko ukur. tahapan selanjutnya rektifikasi positif cast, lakukan pengurangan di bagian proksimal seluruh dinding, 1/3 middle lateral wall (lateral support), 1/3 distal pengurangan mengikuti bentuk cast. Penambahan pada bagian distal cast dengan Panjang penambahan yaitu (seat buttom - (knee buttom + knee axis-socket adaptor + ketebalan resin+ panjang stump )), rektifikasi hasil penambahan, setelah itu, haluskan di seluruh permukaan positif cast dengan wire screen.

Tahap laminasi, tahapan yang menghasilkan hard socket yang terbuat dari resin, fiber glass, stockinet, plastic pvc, tinner, benang / kain perca. setelah tahap laminasi lakukan pembuatan trimline dan lepaskan hard socket dari positif cast menggunakan cast cutter. lakukan penghalusan trimline menggunakan mesin routher sampai halus sehingga tidak melukai pasien.

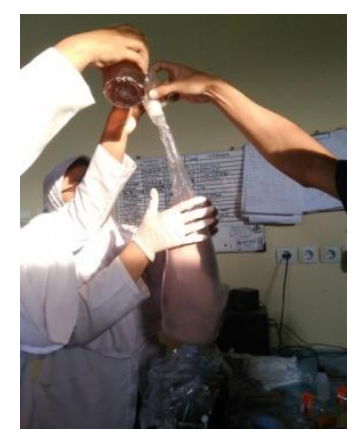

Selanjutnya tahap penyusunan komponen- komponen untuk menjadi 1 prosthesis yang utuh ( assembling). komponen- komponen yang dibutuhkan adalah socket, socket adaptor, polycentric knee joint, tube , tube adaptor, tube clamp, foot adaptor, foot. rangkai komponenkomponen tersebut menggunakan kunci $\mathrm{L}$ , tahapan ini disebut juga dengan bench alignment.

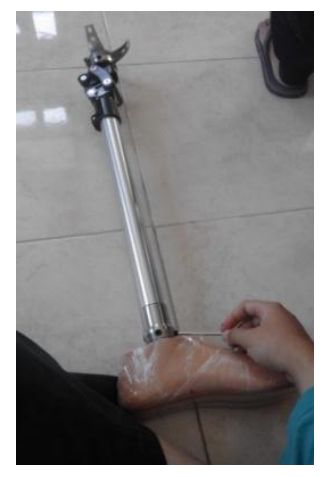

Bench alignment yang bisa dilakukan sesuai dengan kondisi pasien tersebut adalah sebagai berikut socket flexi $15^{\circ}$ karena terdapat kontraktur hip fleksi $15^{\circ}$, socket adduksi $5^{\circ}$, alignment socket pada pandangan anterior adalah $60 \%$ lateral dan $40 \%$ medial, alignment socket pada pandangan lateral adalah $50 \%$ anterior dan $50 \%$ posterior, knee axis $1,5-$ $2 \mathrm{~cm}$ di depan TKA line, knee axis $2 \mathrm{~cm}$ di 
atas MTP, foot $5^{\circ}-7^{\circ}$ external rotasi atau sesuai dengan line of progression.

Tahap kelima adalah fitting atau pengepasan alat ketubuh pasien saat berdiam ( static alignment), yang perlu di check pas tidaknya socket, mengecek bench alignment dan mengecek panjang prosthesis baik saat menggunakan prosthesis yang baru atau yang lama dan saat pasien berjalan menggunakan prosthesis ( dynamic alignment) karena pasien sebelumnya pernah menggunakan prosthesis, tidak perlu diberikan edukasi berjalan dan dapat langsung diminta berjalan menggunakan prosthesis yang lama dan baru, yang dicheck meliputi kondisi pola jalan saat menggunakan prosthesis lama dan baru yang digunakan untuk pembanding.

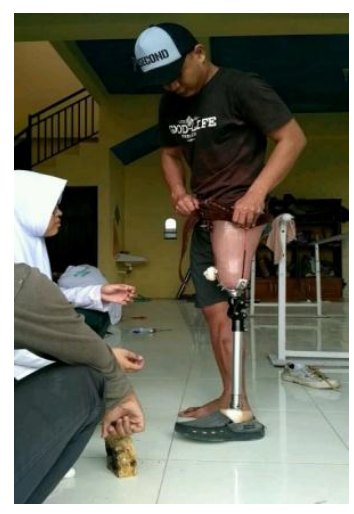

Selanjutnya tahap keenam adalah finishing . tahapan yang dilakukan setelah semua tahapan selasai dengan tujuan untuk memperindah dalam segi kosmesisnya dan dilakukana sebelum prosthesis diserahkan kepada pasien. dan lakukan edukasi kepada pasien tentang cara pemakaian, perawatan stump dan prosthesis.

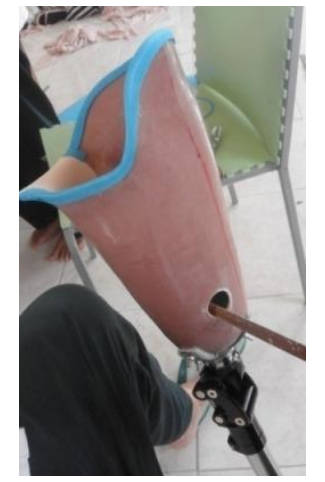

\section{PEMBAHASAN}

Hasil observasi pasien mengalami amputasi transfemoral tungkai kiri, termasuk short stump distal padding yang cukup tebal. Kekuatan otot pasien 4-5 disetiap gerakan. Pasien tidak memiliki riwayat penyakit yang mengharuskan perhatian khusus, dan terdapat bekas jahitan di distal tetapi tidak ada gangguan didaerah tersebut. Pergerakan sendi pasien normal dengan bukti hasil tes stabilitas sendi yang baik dan hasil pengukuran range of motion hip joint pasien yang mendekati normal. Dan terdapat kontraktur hip fleksi $15^{\circ}$.

Dan dari hasil observasi saat menggunakan transfemoral prosthesis dengan single axis manual lock pasien tidak bisa menggunakannya karena merasa tidak stabil sehingga pasien menggunakan sedikit atau tidak menggunakan knee fleksi karena merasa tidak aman atau berbahaya dan ketika digunakan di jalan turunan bisa jatuh jika tidak di lock, sehingga selama menggunakan prosthesis tersebut knee di lock. gait yang deviasi yang muncul adalah circumduction yang disebabkan karena prosthesis terlalu terlalu tinggi 1,5 $\mathrm{cm}$ dari sisi sound side dan knee di lock.

Dan untuk hasil observasi saat menggunakan transfemoral prosthesis dengan polycentric knee joint pada saat 
fitting terdapat gait deviasi medial whip karena knee joint terlalu eksternal rotasi, tinggi prosthesis setelah menggunakan sepatu masih kurang $1,5 \mathrm{~cm}$, dan lateral wall kurang tinggi yang menyebabkan gait deviasi lateral trunk bending. lateral trunk bending dapat muncul ketika pasien berjalan dengan abduction gait. munculnya gait deviasi abduction gait karena merupakan karakteristik dari short stump dan alignment yang tidak tepat. untuk mengatasi kecenderungan shorth stump abduksi gait dengan alignment ulang di adaptor socket yangmana socket diatur abduksi mengikuti karakteristik stump tersebut.

Terdapat rongga di ujung proksimal anterior socket. Pasien merasa lebih stabil saat menggunakan knee joint polycentric dan menghilangkan gait deviasi circumduction. circumduction yang yang salah satu penyebabnya karena knee joint yang dilock. Dari hasil wawancara juga pasien merasa bahwa jalannya ketika memakai single axis knee joint dengan manual lock, merasa ketinggian dan lebih mensupport pada dinding lateral socket. Tetapi walaupun lebih mensupport pada dinding lateral socket dilihat dari jenis knee joint yang digunakan pola jalan pasien lebih baik ketika menggunakan polycentric knee joint.

Pada normal gait terdapat 2 fase yaitu $60 \%$ stance phase dan $40 \%$ swing phase. fase pada normal gait meliputi heel strike - foot flat - mid stance - heel off toe off - acceleration - mid swing deceleration (Perry, 1992).

Pasien transfemoral kehilangan otot yang mengontrol knee joint sehingga pola jalannya berbeda dengan orang normal. saat menggunakan transfemoral dengan polycentric knee joint fase gait yang masih ada adalah: fase heel strike stance - push off - swing (CSPO,1999).

\section{Normal Gait}

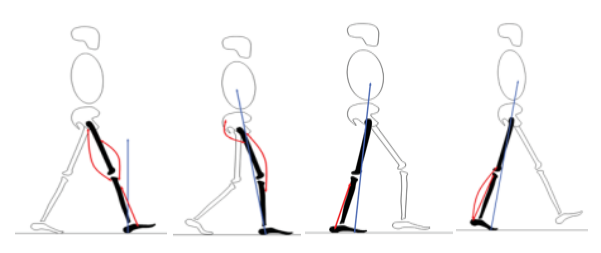

a.heel strike b.foot flat c.mid stance d. heel off

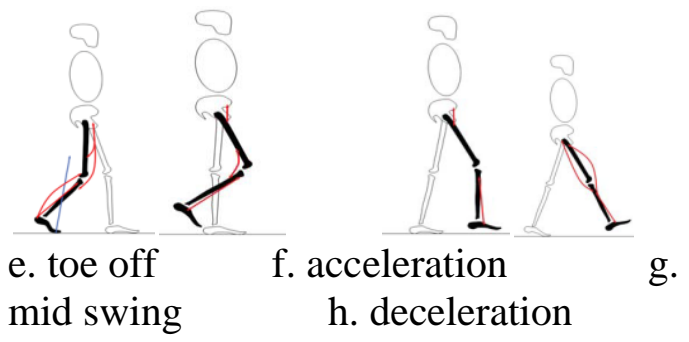

\section{Amputee Gait}
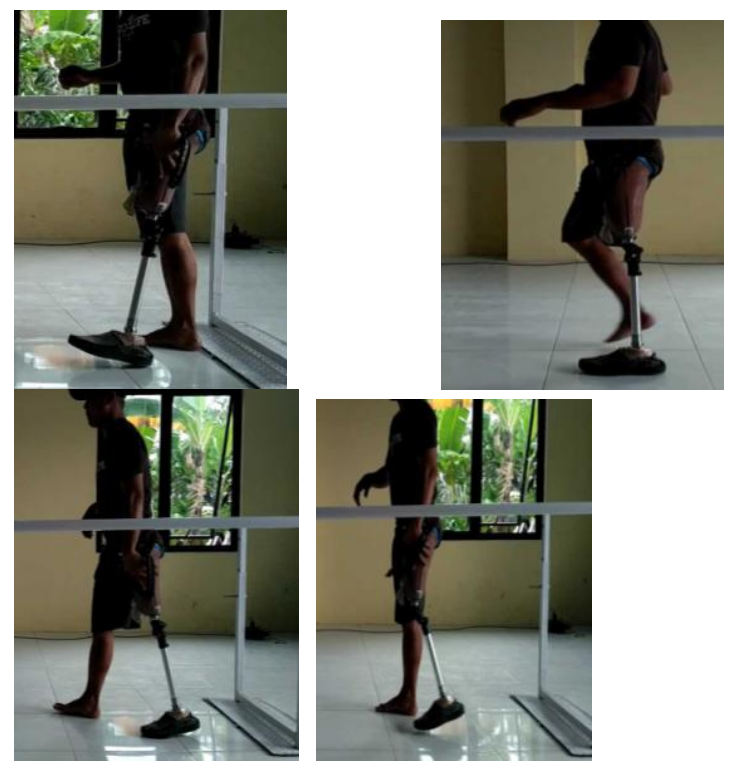

a. heel strike

b.stance

c.push

off 


\section{KESIMPULAN DAN SARAN}

Berdasarkan hasil observasi, wawancara dan analisa yang dilakukan bahwa pembuatan transfemoral prosthesis meliputi: assessment, measurement, casting, fabrication, fitting, dan finishing. Penggunaan polycentric knee joint lebih stabil dari pada single axis knee joint dengan manual lock. stabilitas prosthetic knee adalah faktor penting yang ditetapkan dimana komponen prosthetic knee sebagian besar sesuai dengan kondisi pasien. pasien yang memiliki kesulitan tertentu dalam menstabilisasikan knee, jenis knee yang lebih baik polycentric knee joint dari pada single axis knee joint. untuk mempermudah pasien dalam belajar menstabilkan saat awal stance phase kemudian memperbaiki masalah stabilisasi selanjutnya saat stance phase mintalah bantuan dari prosthetis dan fisioterapi untuk mengajarkannya.

\section{DAFTAR RUJUKAN}

Arelekatti,V.N.M.2016. Design and Preliminary Field Validation of a Fully Passive Prosthetic Knee Mechanism for Users with Transfemoral Amputation in India. ASME Journal of Mechanisms and Robotics.

Basuki, A. M. H. (2006). Penelitian kualitatif untuk ilmu-ilmu kemanusiaan dan budaya. Jakarta: Gunadarma.

Berke, G.M. et.al, 2008; Transfemoral Amputation: The Basic and Beyond. Ottobock Healthcare LP And Prosthetic Research Study.

Gabbiadini S. Knowledge-based design of lower limb prosthesis. Universita Degli Studi Di Padova 2011;113122

http://paduaresearch.cab.unipd.it/3
771/1/PhD_Thesis_Gabbiadini_Ste lla.pdf.

Jumeno, Desto \& adlis,a.w.2009; Desain Prosthesis Endoskeletal Bawah Lutut Untuk Penyandang Cacat; Universitas Andalas Limau Manih, Padang.

Mohanty,R.K., $\quad$ Sabut, $\quad$ S.K., Mohanty,R.C.,2017.Polycentric

Protosthetic Knee Joint: A Review.International Journal Of Engineering, Science And Mathematics. Vol.6(8).

Nolan L, Lees A. The functional demands on the intact limb during walking for active trans-femoral and transtibial amputees. Prosthet Orthot Int.o2000;24:117-125.

Pauley, T., Devlin, M., Heslin, K. Falls sustained during inpatient rehabilitation after lower limb amputation: prevalence and predictors. Am J Phys Med Rehabil. 2006; 85: 521-532.

Perry, Jacquelin.1992. Gait Analysis: Normal and Pathological Function. Thorofare, New Jersey: SLACK Incorporated. ISBN 978-155642-192-1.

Poerwandari, E. K,"Pendekatan Kualitatif untuk Penelitian Perilaku Manusia”,LPSP3.UI, Depok, 2009

Raichle, Katherine., Marisol A Hanley, Ivan Molton, Nancy J. Kadel, Kellye Campbell, Emily Phelps, Dawn Ehde, Douglas G Smith, 2008, Prosthesis Use in Persons With Lower and Upper Limb Amputation, J Rehabil Res Dev, 45.961-972.

Ramakrishnan, T., Lahiff , C.A., Marroquin, A.K., Asgard Kaleb ,Reed, K.B., 2015. Position And Weight Activated Passive 
Prosthetic Knee Mechanism. International Mechanical Engineering Congress and Exposition.

Silver,T.M.B., and Glaister, C.L. Functional stability of transfemoral amputee gait using the 3R80 and total knee 2000 prosthetic knee units. J Prosthet Ortho 2009; 21: 18-31.

Ülger Ö, Topuz S, Bayramlar K. Effects of a hydraulic knee joint on energy consumption, gait and patient satisfaction in trans-femoral amputees.Fizyoter Rehabil. 2009;20(3):169-177.

Vitriana. 2002. www.pustaka.unpad.ac.id. Diakses pada 9 februari 2018. http://pustaka.unpad.ac.id/wpconte nt/uploads/2009/05/rebilitasi_pasie n_amputasi_bawah_lutut.pdf.

Wilig, C, "Introducing Qualitative Research in Psychology: Adventure in Theory and Method", UK: Open University Press, 2001. 